\title{
Family Ties and Socio-Economic Outcomes in High vs Low Income Countries
}

\section{Gianmarco Daniele \& Benny Geys}

To cite this article: Gianmarco Daniele \& Benny Geys (2016): Family Ties and Socio-Economic Outcomes in High vs Low Income Countries, The Journal of Development Studies, DOI: 10.1080/00220388.2015.1098630

To link to this article: http://dx.doi.org/10.1080/00220388.2015.1098630

View supplementary material \lceil

曲 Published online: 26 Jan 2016.

Submit your article to this journal ¿

山 Article views: 30

ai

View related articles $\sqsubset \widehat{T}$

View Crossmark data $־$ 


\title{
Family Ties and Socio-Economic Outcomes in High vs Low Income Countries
}

\author{
GIANMARCO DANIELE**** \& BENNY GEYS ${ }^{\dagger}$ \\ *Department of Applied Economics, Vrije Universiteit Brussel (VUB), Brussels, Belgium, **Institut d'Economia de Barcelona \\ (IEB), Universitat de Barcelona, Barcelona, Spain, ${ }^{\dagger}$ Department of Economics, Norwegian Business School BI, Oslo, Norway
}

(Final version received September 2015; Final version accepted September 2015)

\begin{abstract}
Alesina and Giuliano illustrate that strong family ties lead to lower geographical mobility and reduced labour force participation of young and female individuals. We extend their analysis by arguing that the effect of strong family ties on economic outcomes depends on a country's level of economic and institutional development. This cross-country heterogeneity arises because strong family ties not only foster traditional family values (which have disruptive effects on economic outcomes), but also provide economically valuable social networks - especially in societies characterised by weak institutions and limited market access. Empirical evidence using the European and World Value Surveys (EVS/WVS) are supportive of our theoretical argument.
\end{abstract}

\section{Introduction}

Alesina and Giuliano (2010) show that strong family ties are causally related to several factors disruptive to economic growth, including lower labour force participation of young and female individuals and lower geographical mobility (see also Alesina, Algan, Cahuc, \& Giuliano, 2015; Alesina \& Giuliano, 2013). Subsequent studies illustrate similar negative effects of strong family ties on the labour force participation of elderly individuals, on individuals' interpersonal trust (Alesina \& Giuliano, 2011, 2013; Ermisch \& Gambetta, 2010) and on overall economic dynamism (Duranton, Rodríguez-Pose, \& Sandall, 2009).

In this article, we maintain that allowance should be made for cross-country heterogeneity in the effect of family ties (for similar claims in different settings, see Cervellati, Jung, Sunde, \& Vischer, 2014; Gërxhani, 2004). The underlying argument starts from the observation that existing studies' theoretical reasoning mostly refers to the connection between strong family ties and (traditional) family values. For instance, female labour force participation (LFP) is argued to decline with strong family ties because it is associated with a more traditional view of a woman's role in society (Alesina \& Giuliano, 2010). However, in our view, family ties can also play a key role in the establishment of economically valuable networks (Wahba \& Zenou, 2005) through, for instance, marriages (Luke, Munshi, \& Rosenzweig, 2004; Rosenzweig \& Stark, 1989; Wang, 2013). Rosenzweig and Stark (1989), for instance, show that marital arrangements, which establish a new network with the family of the spouse, mitigate farmers' income volatility in rural India. Luke et al. (2004) similarly find that family networks, again organised around marriages, increase

Correspondence Address: Gianmarco Daniele, Vrije Universiteit Brussel (VUB), Department of Applied Economics, Pleinlaan 2, B-1050 Brussels, Belgium. Email: Daniele.Gianmarco@vub.ac.be

An Online Appendix is available for this article which can be accessed through the online version of this journal available at http://dx.doi.org/10.1080/00220388.2015.1098630

(C) 2016 Taylor \& Francis 
individuals' performance in urban labour markets in both Kenya and India. Wang (2013) uses the exogenous shock of the death of the father-in-law to show the causal effect of family networks on earnings; the loss of the father-in-law is found to induce a 7 per cent decrease in a man's earnings. Hence, family-based networks reflect a capacity to extend one's connections, and might thereby allow access to economically valuable opportunities (Montgomery, 1991; Munshi, 2003, Wahba \& Zenou, 2005). ${ }^{1}$

Crucially, family networks are likely to matter more for economic outcomes in developing countries. At a risk of generalisation, developing countries tend to have weaker formal institutions (Dreher, Méon, \& Schneider, 2014). As informal institutions - such as the family - become a substitute for formal institutions when the latter are incomplete (Dreher et al., 2014; Gërxhani, 2004; Helmke \& Levitsky, 2004), family networks can play a central role for individuals' social and economic needs in such settings. This implies, however, that any positive effect of family networks on labour market outcomes (Luke et al., 2004; Rosenzweig \& Stark, 1989; Wang, 2013) will be particularly forceful in developing countries. Even when there is a general negative impact of traditional family values on LFP (as argued in Alesina et al. [2015] and Alesina and Giuliano [2010, 2013]), the overall effect of strong family ties thus is likely to still vary across countries depending on their level of economic and institutional development. Specifically, one would expect weaker disruptive effects of strong family ties on economic behaviour in less affluent, underdeveloped countries.

A similar argument can also be made for the link between strong family ties and individuals' interpersonal trust. Strong family ties are generally argued to reduce the need for social contacts with people outside the family, because individuals' needs are taken care off within the family (Alesina \& Giuliano, 2013; Ermisch \& Gambetta, 2010). This closed network undermines individuals' ability to judge others' trustworthiness (thereby reducing interpersonal trust), and decreases their access to opportunities outside the family (impeding their economic progress). ${ }^{2}$ Yet, this line of argument again pays too little attention to the potential role of family networks in developing, low-income countries. In such settings, as mentioned, the network effects induced by strong family ties emphatically increase people's contact possibilities outside the family and buttress the availability of economically valuable opportunities (Luke et al., 2004; Rosenzweig \& Stark, 1989; Wang, 2013). As before, therefore, the effect of strong family ties on social trust is likely to display cross-country heterogeneity depending on countries' levels of economic and institutional development.

Section 2 describes the dataset and estimation strategy employed to test for cross-country heterogeneity in the effect of family ties on economic outcomes. The main findings are summarised in Section 3. Finally, Section 4 contains a concluding discussion.

\section{Data and Estimation Approach}

Following Alesina and Giuliano (2010, 2011, 2013), our empirical analysis is based on data from all currently completed waves of the EVS/WVS. This dataset covers 99 countries and roughly 220,000 individuals (though not all countries are represented in every wave). Using these data, we estimate the following regression equation (where $i$ refers to individuals and $t$ to survey waves):

$$
\mathrm{Y}_{\mathrm{i}, \mathrm{t}}=\mathrm{a}+\mathrm{b}_{1} \text { Family } \text { Ties }_{\mathrm{i}, \mathrm{t}}+\mathrm{b}_{2} \text { Controls }_{\mathrm{i}, \mathrm{t}}+\mathrm{e}_{\mathrm{i}, \mathrm{t}}
$$

$Y_{i, t}$ is a vector containing measures of young, female and elderly labour force participation (that is, indicator variables equal to 1 if the respondent is active in the labour market, 0 otherwise), geographical mobility (that is, indicator variable equal to 1 if the respondent is co-resident in his/her parents' house [Alesina \& Giuliano, 2010]) and interpersonal trust (that is, indicator variable equal to 1 if the respondent believes that most people can be trusted). The actual survey question on interpersonal trust reads: 'Generally speaking would you say that most people can be trusted or that you can't be too 
careful in dealing with people?' Respondents can either agree with the former part of the statement (in which case they are coded as 1 in our trust measure), or with the latter part of the statement (in which case they receive value 0 ). Note also that young (elderly) individuals are defined as between 15 and 29 (55 and 65) years of age.

Our measure of the strength of family ties combines information from three separate survey questions (Alesina et al., 2015; Alesina \& Giuliano, 2010, 2011, 2013; Bertrand \& Schoar, 2006). These are, respectively, related to family's importance to the respondent, his/her evaluation of the duties and responsibilities of parents towards children, and his/her evaluation of children's duties and responsibilities towards their parents. $^{3}$ We combine these questions using a principal components analysis (PCA), and employ the first principal component as our main explanatory variable. ${ }^{4}$ As shown in detail by Alesina and Giuliano (2013), Scandinavian and Anglo-Saxon countries rank lowest on the resulting scale, while a heterogeneous group of African, Asian and South American countries rank highest. It is clear from the questions employed (see note 3 ) that our analysis is predominantly based on measures of family values and does not explicitly introduce a direct measure of family networks. Still, our underlying assumption is that the strength of family values is related positively to the strength of family networks. Although the two concepts are clearly different, it is plausible to assume a positive correlation between them, which is all we require for the analysis below.

The vector Controls $_{i, t}$ contains variables reflecting individuals' sex, age, age squared, marital status and education, as well as country and survey fixed effects and the interaction of survey and country fixed effects. Although this follows Alesina and Giuliano (2010, 2013), we also experimented with a more extended set of controls incorporating individuals' income and religiosity. As this does not affect any of the inferences below, we do not report these additional results in detail here. Summary statistics for all variables are provided in Table 1.

Table 1. Summary statistics

\begin{tabular}{|c|c|c|c|c|c|}
\hline Variable & Observations & Mean & Std Dev. & Min & Max \\
\hline Family ties (see Section 3 for details) & 269085 & $8.76 \mathrm{E}-09$ & 1.111511 & -5.84373 & 0.789682 \\
\hline Trust (see Section 3 for details) & 405490 & 0.29075 & 0.454109 & 0 & 1 \\
\hline LFP (see Section 3 for details) & 405271 & 0.635197 & 0.481375 & 0 & 1 \\
\hline $\begin{array}{l}\text { Geographical mobility (see Section } 3 \text { for } \\
\text { details) }\end{array}$ & 318494 & 0.275236 & 0.446634 & 0 & 1 \\
\hline Interest in politics & 380171 & 2.640827 & 0.959913 & 4 & 1 \\
\hline Sign petition & 379239 & 2.001566 & 0.816958 & 3 & 1 \\
\hline Joining in boycotts & 368583 & 2.498189 & 0.658263 & 3 & 1 \\
\hline Attending demonstrations & 377978 & 2.281715 & 0.745397 & 3 & 1 \\
\hline Joining strikes & 302315 & 2.699152 & 0.559341 & 3 & 1 \\
\hline Occupying buildings & 297367 & 2.829285 & 0.430827 & 3 & 1 \\
\hline Age & 413876 & 42.14841 & 16.7231 & 14 & 108 \\
\hline Sex ( 1 for female, 0 for male $)$ & 419345 & 0.525424 & 0.499354 & 0 & 1 \\
\hline Married ( 1 for married, 0 otherwise) & 424099 & 0.045808 & 0.209068 & 0 & 1 \\
\hline $\begin{array}{l}\text { Education ( } 1 \text { for lower education, } 2 \text { for middle } \\
\text { education, } 3 \text { for higher education) }\end{array}$ & 338262 & 1.865442 & 0.739948 & 1 & 3 \\
\hline $\begin{array}{l}\text { Income ( } 1 \text { for lowest income, } 10 \text { for highest } \\
\text { income) }\end{array}$ & 308616 & 4.65622 & 2.438972 & 1 & 10 \\
\hline $\begin{array}{l}\text { Religiosity ( } 1 \text { if the respondent belongs to a } \\
\text { religious denomination, } 0 \text { otherwise) }\end{array}$ & 329054 & 0.79418 & 0.4043 & 0 & 1 \\
\hline Survey Wave ( 1 for 1 st wave, 6 for last wave) & 424099 & 3.823836 & 1.487118 & 1 & 6 \\
\hline $\begin{array}{l}\text { World Bank development classification } \\
\text { (see Section } 3 \text { for details) }\end{array}$ & 420319 & 2.95035 & 1.032966 & 1 & 4 \\
\hline $\begin{array}{l}\text { Government effectiveness (see Section } 3.2 \text { for } \\
\text { details) }\end{array}$ & 311922 & 2.937157 & 1.010256 & 1 & 4 \\
\hline Regulatory quality (see Section 3.2 for details) & 320577 & 2.977016 & 1.027109 & 1 & 4 \\
\hline Rule of law (see Section 3.2 for details) & 330136 & 2.766151 & 1.077019 & 1 & 4 \\
\hline
\end{tabular}




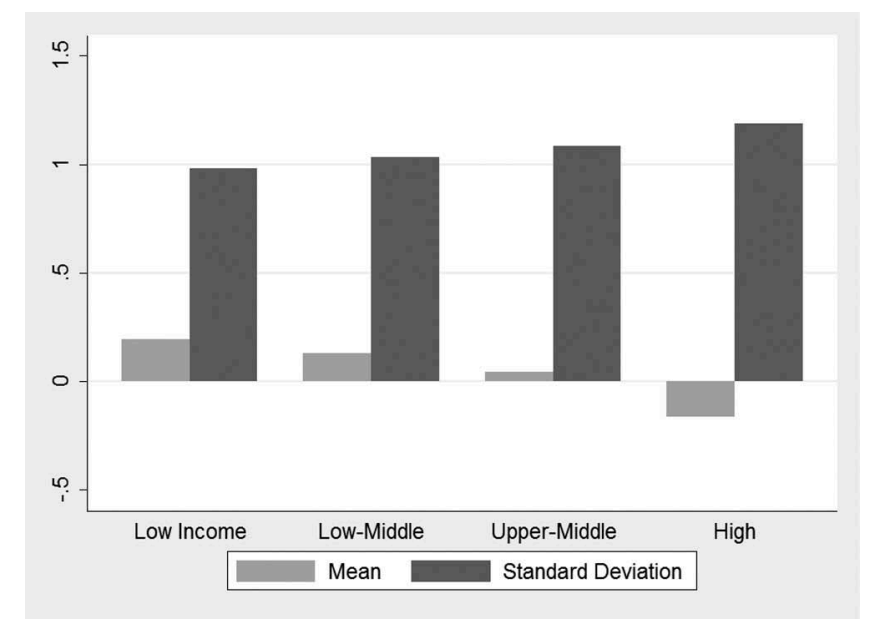

Figure 1. Family ties means and standard deviations.

Notes: The $\mathrm{x}$ axis shows the four groups of countries distinguished by the World Bank development classification. The y axis presents average levels and standard deviations of the family ties' variable (higher values correspond to stronger family ties).

To test for cross-country heterogeneity in the effect of family ties, we run Equation (1) for different subcategories of countries depending on their level of economic and institutional development using the World Bank development classification. ${ }^{5}$ This classification is based on gross national income (GNI) per capita, and separates four groups of countries: that is, low income; low-medium income; upper-medium income; and high income. Although we test the robustness of our results to this classification below, we use it in the main analysis for three reasons. First, it is a well-established indicator of countries' development. Second, GNI per capita is strongly positively correlated with the strength of formal institutions, which represents the key driving force behind our theoretical argument in Section 2. Finally, the World Bank classification started in 1987 and is updated annually. This allows incorporating countries' development over time, which is important since most countries in our sample (60 out of 99) switch category over the four decades covered by our analysis (note that such switches are not necessarily upwards). Figure 1 illustrates means and standard deviations of the family ties' variable in the four groups of countries. In line with Alesina and Giuliano (2010, 2013), family ties weaken with a country's level of development, although, importantly, significant variation remains within each group of countries.

Before discussing the results, it is important to note that Alesina and Giuliano (2010) deal extensively with the problem of reverse causality - that is, the fact that individuals suffering economic misfortune need to rely more heavily on their family's resources, which might impact their perception of family ties - by looking at inherited family ties among a subsample of second-generation immigrants. The key identifying assumption is that the strength of family ties is generally persistent across generations and is related to historical family structures (Galasso \& Profeta, 2012). To preserve space, and because we rely on the same dataset as Alesina and Giuliano (2010, 2013), our analysis will not repeat these causality tests.

\section{Results}

\subsection{Baseline Results}

Table 2 reports our main findings using OLS. ${ }^{6}$ In column 1 , we employ the full sample of countries as in Alesina and Giuliano $(2010,2011,2013)$. Columns 2 to 5 report results for, respectively, the subsample of low income (column 2), low-middle income (column 3), middle-upper income 
Table 2. Main results on family ties, trust and economic outcomes

\begin{tabular}{|c|c|c|c|c|c|}
\hline & $\begin{array}{l}\text { Entire } \\
\text { sample }\end{array}$ & $\begin{array}{l}\text { Low } \\
\text { income }\end{array}$ & $\begin{array}{l}\text { Low-middle } \\
\text { income }\end{array}$ & $\begin{array}{l}\text { Upper-middle } \\
\text { income }\end{array}$ & $\begin{array}{l}\text { High } \\
\text { income }\end{array}$ \\
\hline \multicolumn{6}{|l|}{ Trust } \\
\hline Family ties & $\begin{array}{l}-0.006 \\
(6.67)^{* *}\end{array}$ & $\begin{array}{c}0.014 \\
(5.03)^{* *}\end{array}$ & $\begin{array}{l}-0.003 \\
(1.50)\end{array}$ & $\begin{array}{l}-0.008 \\
(4.91)^{* *}\end{array}$ & $\begin{array}{l}-0.010 \\
(6.82)^{* *}\end{array}$ \\
\hline Controls $A \& G$ & YES & YES & YES & YES & YES \\
\hline$R^{2}$ & 0.11 & 0.05 & 0.12 & 0.05 & 0.13 \\
\hline$N$ & 218,465 & 28,385 & 48,853 & 59,512 & 78,330 \\
\hline \multicolumn{6}{|l|}{ Women LFP } \\
\hline Family ties & $\begin{array}{l}-0.008 \\
(5.45)^{* *}\end{array}$ & $\begin{array}{l}-0.005 \\
(1.21)\end{array}$ & $\begin{array}{c}-0.008 \\
(2.50)^{*}\end{array}$ & $\begin{array}{l}-0.010 \\
(3.66)^{* *}\end{array}$ & $\begin{array}{l}-0.007 \\
(3.42)^{* *}\end{array}$ \\
\hline Controls $A \& G$ & YES & YES & YES & YES & YES \\
\hline$R^{2}$ & 0.24 & 0.27 & 0.23 & 0.24 & 0.20 \\
\hline$N$ & 98,779 & 12,320 & 23,242 & 27,662 & 34,029 \\
\hline \multicolumn{6}{|l|}{ Young LFP } \\
\hline Family ties & $\begin{array}{l}-0.005 \\
(3.61)^{* *}\end{array}$ & $\begin{array}{r}0.003 \\
(0.82)\end{array}$ & $\begin{array}{c}-0.006 \\
(2.01)^{*}\end{array}$ & $\begin{array}{l}-0.007 \\
(2.84)^{* *}\end{array}$ & $\begin{array}{l}-0.008 \\
(4.25)^{* *}\end{array}$ \\
\hline Controls $A \& G$ & YES & YES & YES & YES & YES \\
\hline$R^{2}$ & 0.31 & 0.41 & 0.32 & 0.29 & 0.19 \\
\hline$N$ & 44,601 & 7,144 & 11,969 & 13,229 & 11,708 \\
\hline \multicolumn{6}{|c|}{ Geographical mobility } \\
\hline Family ties & $\begin{array}{l}-0.004 \\
(4.34)^{* *}\end{array}$ & $\begin{array}{c}0.003 \\
(1.10)\end{array}$ & $\begin{array}{l}-0.002 \\
(1.27)\end{array}$ & $\begin{array}{l}-0.003 \\
(1.95)\end{array}$ & $\begin{array}{l}-0.005 \\
(3.92)^{* *}\end{array}$ \\
\hline Controls $A \& G$ & YES & YES & YES & YES & YES \\
\hline$R^{2}$ & 0.38 & 0.36 & 0.36 & 0.39 & 0.38 \\
\hline$N$ & 44,601 & 29,655 & 43,468 & 40,931 & 44,875 \\
\hline \multicolumn{6}{|l|}{ Elderly LFP } \\
\hline Family ties & $\begin{array}{l}-0.005 \\
(1.89)\end{array}$ & $\begin{array}{c}0.000 \\
(0.05)\end{array}$ & $\begin{array}{l}-0.009 \\
(1.35)\end{array}$ & $\begin{array}{l}-0.001 \\
(0.11)\end{array}$ & $\begin{array}{c}-0.006 \\
(1.47)\end{array}$ \\
\hline Controls $A \& G$ & YES & YES & YES & YES & YES \\
\hline$R^{2}$ & 0.26 & 0.30 & 0.26 & 0.24 & 0.28 \\
\hline$N$ & 27,182 & 2,058 & 5,470 & 7,653 & 11,431 \\
\hline
\end{tabular}

Notes: OLS estimations, t-statistics based on robust standard errors between brackets. The dependent variables are: Trust - 'Generally speaking would you say that most people can be trusted or that you can't be too careful in dealing with people?' ( 1 if the respondent agrees that most people can be trusted); Female, young and elderly LFP are dummies equal to 1 if the respondent is active in the labour market, 0 otherwise; Geographical mobility is a dummy equal to 1 if the respondent lives with his/her parents. Countries are divided into four groups based on the World Bank development classification. Control variables in this model include gender, age, age squared, marital status, education level, survey fixed effects, country fixed effects and interactions between country and survey fixed effects. ${ }^{*} p<0.05 ;{ }^{* *} p<0.01$.

(column 4) and high income (column 5) countries. To preserve space, and because they are generally equivalent to those reported in Alesina and Giuliano (2010, 2011, 2013), we do not present the coefficients of the control variables.

Column 1 shows that the effect of strong family ties on the different dependent variables in the entire sample is similar, both in terms of effect size and statistical significance, to Alesina and Giuliano $(2010,2011,2013) .^{7}$ Specifically, family ties have a negative and substantively meaningful effect on social trust, geographical mobility, female and youth LFP, but do not significantly affect elderly LFP. The remaining columns in Table 2 , however, indicate that this negative relation is mostly driven by developed, high-income countries. Indeed, while all coefficient estimates in column 5 are negative and statistically significant (except for elderly LFP), moving towards less-developed, lower-income countries leads to substantively and/or statistically weaker effect sizes for female and young LFP. For the measures of geographical mobility and interpersonal trust, the negative effect of strong family ties is even reversed when the level of development is sufficiently low. Except for elderly and female LFP, 
we can thereby formally reject at conventional levels of statistical significance that the effect of strong family ties is the same across all countries.

These findings should not be interpreted as a rebuttal of Alesina and Giuliano (2010, 2011, 2013). Our results do, however, provide a valuable extension by confirming important cross-country heterogeneity in the effect of family ties - especially when looking at countries with the lowest levels of economic and institutional development. Note also that these results cannot be explained by potential differences in the level of variation observed in family ties across the four subsamples and particularly within the low-income countries. Figure 1 indeed illustrates that significant variation exists within each group of countries, and that there are only marginal differences in the observed standard deviations across groups.

The exception posed by the results on female LFP - where the estimated effect sizes are roughly equivalent across all country groups - is interesting from a theoretical perspective. This indeed appears to suggest that the positive family networks effect counteracting the negative family values effect in low-income countries (see above) lacks substantive power for female LFP. Such interpretation could be in line with Magruder (2010), who shows that the labour market advantage of family networks in South Africa arises only for men, not for women. Family networks might thus be less useful for women than for men in low-income countries, which becomes reflected in the relative homogeneity of our findings across countries on this variable. ${ }^{8}$ Alternatively, however, it may also be that for female LFP, the negative family values effect strengthens in equal measure to the family networks effect while moving towards less developed countries.

As a preliminary step towards disentangling both explanations, we experimented with individuals' actual employment status (that is, an indicator variable equal to 1 if employed, 0 otherwise) as an alternative dependent variable. Assuming that traditional family values mainly affect the decision to enter (or not) the labour market (see Alesina \& Giuliano, 2010), looking at employment outcomes given that individuals participate in the labour force provides an indicator for the strength of family network effects on economic outcomes. Using a Heckman selection model to account for the effect of family ties on female LFP (see above), the results indicate that strong family ties positively affect female employment only in developing low-income countries (details upon request). Although this is suggestive of the fact that women also benefit from a positive family networks effect, it clearly requires further confirmation in future research.

\subsection{Robustness Check Using Alternative Country Classification}

In this section, we experiment with different measures of institutional quality to approximate economic and institutional development. Specifically, we consider three indicators included in the World Bank's worldwide governance indicators (WGI). These aggregate information from dozens of indicators, and are updated annually since 1996. The measures included here are: (i) Government Effectiveness, which assesses the quality of policy formulation and implementation, public services and the civil service as well as the degree of its independence from political pressures; (ii) Regulatory Quality, which measures the government's ability to formulate and implement high-quality policies and regulations; (iii) Rule of Law, which evaluates 'the quality of contract enforcement, property rights, the police, and the courts, as well as the likelihood of crime and violence' (Worldwide Governance Indicators, http://www.govindicators.org).

The WGI place each country in a percentile rank according to their position in the global ranking. Higher positions thereby reflect better outcomes. To align our presentation to that of previous tables, we use the original scores to divide countries in four distinct groups: that is, low quality institutions (0-25); low-middle quality institutions (26-50); upper-middle quality institutions (51-75); and high quality institutions (76-100). We then re-estimate Equation (1) separately for these four groups of countries. The results concerning Government Effectiveness are provided in Table 3 (Regulatory Quality and Rule of Law provide similar findings, which are available upon request). Note that the sample is restricted here to data collected after 1995, since WGI data are available only since 1996 . 
Table 3. Alternative operationalisation of economic development.

\begin{tabular}{|c|c|c|c|c|}
\hline & $\begin{array}{c}\text { Low } \\
\text { government } \\
\text { effectiveness }\end{array}$ & $\begin{array}{l}\text { Lower-middle } \\
\text { government } \\
\text { effectiveness }\end{array}$ & $\begin{array}{l}\text { Upper-middle } \\
\text { government } \\
\text { effectiveness }\end{array}$ & $\begin{array}{c}\text { High } \\
\text { government } \\
\text { Effectiveness }\end{array}$ \\
\hline \multicolumn{5}{|l|}{ Trust } \\
\hline Family ties & $\begin{array}{l}0.008 \\
(2.40)^{*}\end{array}$ & $\begin{array}{c}-0.003 \\
(1.35)\end{array}$ & $\begin{array}{c}-0.001 \\
(0.31)\end{array}$ & $\begin{array}{l}-0.011 \\
(7.19)^{* *}\end{array}$ \\
\hline Controls $A \& G$ & YES & YES & YES & YES \\
\hline$R^{2}$ & 0.05 & 0.11 & 0.07 & 0.14 \\
\hline$N$ & 21,516 & 45,223 & 50,869 & 77,066 \\
\hline \multicolumn{5}{|l|}{ Women LFP } \\
\hline Family ties & $\begin{array}{c}-0.006 \\
(1.47)\end{array}$ & $\begin{array}{c}-0.005 \\
(1.47)\end{array}$ & $\begin{array}{l}-0.005 \\
(1.60)\end{array}$ & $\begin{array}{l}-0.009 \\
(4.28)^{* *}\end{array}$ \\
\hline Controls $A \& G$ & YES & YES & YES & YES \\
\hline$R^{2}$ & 0.25 & 0.24 & 0.26 & 0.19 \\
\hline$N$ & 10,335 & 20,768 & 23,882 & 32,868 \\
\hline \multicolumn{5}{|l|}{ Young LFP } \\
\hline Family ties & $\begin{array}{c}0.004 \\
(1.08)\end{array}$ & $\begin{array}{c}-0.003 \\
(0.90)\end{array}$ & $\begin{array}{l}-0.007 \\
(2.63)^{* *}\end{array}$ & $\begin{array}{l}-0.007 \\
(3.62)^{* *}\end{array}$ \\
\hline Controls $A \& G$ & YES & YES & YES & YES \\
\hline$R^{2}$ & 0.05 & 0.11 & 0.07 & 0.14 \\
\hline$N$ & 21,516 & 45,223 & 50,869 & 77,066 \\
\hline \multicolumn{5}{|c|}{ Geographical Mobility } \\
\hline Family ties & $\begin{array}{c}-0.002 \\
(0.72)\end{array}$ & $\begin{array}{c}-0.001 \\
(0.64)\end{array}$ & $\begin{array}{c}0.004 \\
(1.80)\end{array}$ & $\begin{array}{c}0.004 \\
(3.43)^{* *}\end{array}$ \\
\hline Controls $A \& G$ & YES & YES & YES & YES \\
\hline$R^{2}$ & 0.38 & 0.39 & 0.33 & 0.37 \\
\hline$N$ & 19,610 & 37,471 & 35,312 & 49,818 \\
\hline \multicolumn{5}{|l|}{ Elderly LFP } \\
\hline Family ties & $\begin{array}{r}-0.017 \\
(1.80)\end{array}$ & $\begin{array}{c}-0.010 \\
(1.37)\end{array}$ & $\begin{array}{c}0.002 \\
(0.41)\end{array}$ & $\begin{array}{c}-0.006 \\
(1.43)\end{array}$ \\
\hline Controls $A \& G$ & YES & YES & YES & YES \\
\hline$R^{2}$ & 0.29 & 0.26 & 0.26 & 0.28 \\
\hline$N$ & 2,149 & 4,721 & 6,006 & 11,086 \\
\hline
\end{tabular}

Notes: OLS estimations, t-statistics based on robust standard errors between brackets. The dependent variables are: Trust - 'Generally speaking would you say that most people can be trusted or that you can't be too careful in dealing with people?' ( 1 if the respondent agrees that most people can be trusted); Female, young and elderly LFP are dummies equal to 1 if the respondent is active in the labour market, 0 otherwise; Geographical mobility is a dummy equal to 1 if the respondent lives with his/her parents. Countries are divided into four groups based on government effectiveness (see Section 3.2 for details). Control variables in this model include gender, age, age squared, marital status, education level, survey fixed effects, country fixed effects and interactions between country and survey fixed effects. ${ }^{*} p<0.05 ; * * p 0.01$.

Despite the shorter period and the alternative operationalisation of countries' level of development, the results in Table 3 are a close replication of those in Table 2; that is, strong family ties have a meaningful negative effect on trust, geographical mobility, female and youth LFP in countries with high-quality formal institutions. However, moving towards less-developed countries in the left-hand side of the table generally weakens this negative relation, and in some cases reverses it. This confirms that our results are robust to different classifications of countries' economic and institutional development.

\subsection{Robustness Check on Political Engagement}

Our theoretical argument relies on the substantial potential economic value of family networks in lessdeveloped countries. We can assess this theoretical mechanism by evaluating whether the link between 
family ties and non-economic outcomes (such as political interest and political engagement) differs depending on countries' level of economic and institutional development. As the economic value of family networks should have no effect on non-economic outcomes, we would not expect to observe cross-country heterogeneity in the effect of family ties on non-economic outcomes. This test is inspired by Alesina and Giuliano (2011), who show that the detrimental effects of strong family ties extend to political interest and political engagement. The underlying argument relies on Banfield's (1967) theory of 'amoral familism', which holds that strong family ties might act as a substitute for interest in public affairs. All attention under such 'amoral familism' is directed inwards - that is, towards the needs and aspirations of one's immediate family circle - and leads to a disregard for external, non-family issues (for more details, see Alesina \& Giuliano [2011]).

In Table 4, we report the results from re-estimating model (1) using different measures of political participation as dependent variables. For reasons of comparability, we thereby use the same dependent variables as Alesina and Giuliano (2011): that is, interest in politics (measured on a four-point scale from (1) 'not at all interested' to (4) 'very interested'), and individuals' likelihood to sign a petition, join a boycott, attend demonstrations and occupy buildings (measured on a three-point scale including (1) 'Would never do', (2) 'might do' and (3) 'have done'). Table 4 follows the same basic pattern as Table $2 .^{9}$

The results in Table 4 indicate that family ties negatively affect political participation for all dependent variables included in the analysis - in line with the original results reported in Alesina and Giuliano (2011). Importantly, this observation holds both for the entire set of countries (column 1), as well as the four subsets based on World Bank development categories (columns 2 to 5). Overall, this provides further substantiation of our results in Tables 2 and 3, since a heterogeneous effect of family ties appears only on the (economic) variables targeted by our theoretical line of argument.

\section{Conclusion}

Recent work has shown that strong family ties have a detrimental effect on several sources of economic growth including interpersonal trust, geographical mobility and young, female and elderly LFP (Alesina et al., 2015; Alesina \& Giuliano, 2010, 2011, 2013). In this article, we have argued that allowance should be made for cross-country heterogeneity in this effect of family ties. The underlying idea is that in developing countries, where institutions and markets are weaker (Dreher et al., 2014; Gërxhani, 2004; Helmke \& Levitsky, 2004), strong family ties will act as a substitute for the market and can have important - and economically valuable - network effects that counteract the negative effect of (traditional) family values.

Our empirical analysis provides evidence in line with this idea. Strong family ties only have a substantive, statistically significant negative effect on labour force participation, trust and geographical mobility in developed high-income countries. This negative relation disappears - and can even reverse - at lower levels of development, where family networks become more economically valuable as a substitute for market access. These results are robust to different measures of economic development. Moreover, a robustness check on non-economic outcomes corroborates that the observed heterogeneity may indeed derive from the economic value of family networks in under-developed countries.

These results not only highlight the importance of accounting for the various, and sometimes contrasting, effects of strong family ties on economic behaviour, but also raise a number of important avenues for future research. For instance, they emphasise the need for a deeper understanding of the exact relations and trade-offs between formal and informal institutions (such as the family). While the family unit has rightly been recognised as central to economic behaviour, our knowledge of how the role of family ties interacts with the effects of formal institutions remains overly limited. A recent exception to this general trend is Durante, Labartino, and Perotti (2015), who show that a 1998 legislative reform in Italy weakening the institutional constraints on the academic hiring process 
Table 4. Political engagement.

\begin{tabular}{|c|c|c|c|c|c|}
\hline & $\begin{array}{l}\text { Entire } \\
\text { sample }\end{array}$ & $\begin{array}{l}\text { Low } \\
\text { income }\end{array}$ & $\begin{array}{l}\text { Low-middle } \\
\text { income }\end{array}$ & $\begin{array}{l}\text { Upper-middle } \\
\text { income }\end{array}$ & $\begin{array}{l}\text { High } \\
\text { income }\end{array}$ \\
\hline \multicolumn{6}{|c|}{ Interest in politics } \\
\hline Family ties & $\begin{array}{l}-0.013 \\
(7.05)^{* *}\end{array}$ & $\begin{array}{l}-0.016 \\
(2.71)^{* *}\end{array}$ & $\begin{array}{c}0.002 \\
(0.43)\end{array}$ & $\begin{array}{l}-0.024 \\
(6.47)^{* *}\end{array}$ & $\begin{array}{l}-0.011 \\
(4.02)^{* *}\end{array}$ \\
\hline Controls $A \& G$ & YES & YES & YES & YES & YES \\
\hline$R^{2}$ & 0.15 & 0.11 & 0.14 & 0.14 & 0.17 \\
\hline$N$ & 212,931 & 28,490 & 47,915 & 55,254 & 77,788 \\
\hline \multicolumn{6}{|l|}{ Sign petition } \\
\hline Family ties & $\begin{array}{l}-0.026 \\
(17.21)^{* *}\end{array}$ & $\begin{array}{l}-0.037 \\
(7.94)^{* *}\end{array}$ & $\begin{array}{l}-0.024 \\
(6.55)^{* *}\end{array}$ & $\begin{array}{l}-0.032 \\
(11.06)^{* *}\end{array}$ & $\begin{array}{c}-0.040 \\
(17.41)^{* *}\end{array}$ \\
\hline Controls $A \& G$ & YES & YES & YES & YES & YES \\
\hline$R^{2}$ & 0.28 & 0.12 & 0.13 & 0.18 & 0.25 \\
\hline$N$ & 206,678 & 26,135 & 43,409 & 57,856 & 76,071 \\
\hline \multicolumn{6}{|c|}{ Joining in boycotts } \\
\hline Family ties & $\begin{array}{l}-0.045 \\
(33.22)^{* *}\end{array}$ & $\begin{array}{l}-0.035 \\
(8.68)^{* *}\end{array}$ & $\begin{array}{l}-0.028 \\
(9.06)^{* *}\end{array}$ & $\begin{array}{l}-0.039 \\
(15.61)^{* *}\end{array}$ & $\begin{array}{l}-0.055 \\
(25.62)^{* *}\end{array}$ \\
\hline Controls $A \& G$ & YES & YES & YES & YES & YES \\
\hline$R^{2}$ & 0.19 & 0.15 & 0.18 & 0.14 & 0.20 \\
\hline$N$ & 201,627 & 26,203 & 41,992 & 57,080 & 73,177 \\
\hline \multicolumn{6}{|c|}{ Attending demonstrations } \\
\hline Family ties & $\begin{array}{l}-0.031 \\
(20.81)^{* *}\end{array}$ & $\begin{array}{l}-0.022 \\
(4.48)^{* *}\end{array}$ & $\begin{array}{l}-0.022 \\
(6.19)^{* *}\end{array}$ & $\begin{array}{l}-0.023 \\
(8.17)^{* *}\end{array}$ & $\begin{array}{l}-0.040 \\
(17.41)^{* *}\end{array}$ \\
\hline Controls $A \& G$ & YES & YES & YES & YES & YES \\
\hline$R^{2}$ & 0.16 & 0.11 & 0.16 & 0.10 & 0.17 \\
\hline$N$ & 207,089 & 26,527 & 44,144 & 57,857 & 75,382 \\
\hline \multicolumn{6}{|l|}{ Joining strikes } \\
\hline Family ties & $\begin{array}{l}-0.039 \\
(31.73)^{* *}\end{array}$ & $\begin{array}{l}-0.041 \\
(10.52)^{* *}\end{array}$ & $\begin{array}{l}-0.024 \\
(9.42)^{* *}\end{array}$ & $\begin{array}{l}-0.037 \\
(16.00)^{* *}\end{array}$ & $\begin{array}{l}-0.044 \\
(22.89)^{* *}\end{array}$ \\
\hline Controls $A \& G$ & YES & YES & YES & YES & YES \\
\hline$R^{2}$ & 0.11 & 0.08 & 0.09 & 0.09 & 0.11 \\
\hline$N$ & 200,626 & 26,143 & 43,673 & 56,137 & 71,675 \\
\hline \multicolumn{6}{|c|}{ Occupying buildings } \\
\hline Family ties & $\begin{array}{l}-0.028 \\
(28.98)^{* *}\end{array}$ & $\begin{array}{l}-0.020 \\
(8.08)^{* *}\end{array}$ & $\begin{array}{l}-0.011 \\
(5.90)^{* *}\end{array}$ & $\begin{array}{l}-0.030 \\
(15.67)^{* *}\end{array}$ & $\begin{array}{l}-0.034 \\
(21.36)^{* *}\end{array}$ \\
\hline Controls $A \& G$ & YES & YES & YES & YES & YES \\
\hline$R^{2}$ & 0.10 & 0.15 & 0.04 & 0.08 & 0.11 \\
\hline$N$ & 199,111 & 25,851 & 43,534 & 56,869 & 69,831 \\
\hline
\end{tabular}

Notes: OLS estimations, t-statistics based on robust standard errors between brackets. 'Interest in politics' is measured as: 'How interested would you say you are in politics?' (from (1) not at all interested to (4) very interested). The remaining dependent variables derive from the following question: 'I'm going to read out some forms of political action that people can take, and I'd like you to tell me, for each one, whether you have done any of these things (3), whether you might do it (2) or would never under any circumstances do it (1): Signing a petition; Joining in boycotts; Attending lawful demonstrations; Joining unofficial strikes; Occupying buildings or factories.' Countries are divided into four groups based on the World Bank development classification. Control variables in this model include gender, age, age squared, marital status, education level, survey fixed effects, country fixed effects and interactions between country and survey fixed effects. ${ }^{*} p<0.05 ;{ }^{*} p<0.01$.

caused a significant increase in the prevalence and persistence of family-based hiring practices only in areas characterised by low civic capital. Similarly, Alesina et al. (2015) argue that the deregulation of formal labour market institutions 'requires geographical mobility', which in turn 'requires relatively weak family ties'. Still, as we have shown, the negative link between strong family ties and geographical mobility holds only in a subset of affluent countries, such that the apparent general nature of their conclusion would require a more in-depth assessment in future research. 
Clearly, a better understanding of such interactions between formal and informal institutions is of critical importance to a more accurate design of public policies. In fact, since similar self-reported attitudes towards family ties lead to opposite outcomes depending on the socio-economic characteristics of the country, it is important for public policy-makers aiming at, for instance, labour market regulation, redistributive policies, education and welfare provision to properly account for the exact influence of family ties in their setting. ${ }^{10}$

\section{Acknowledgements}

The authors are grateful to Alberto Alesina and Paola Giuliano for access to their data and stata code, and thank Bruno Heyndels, Joshua Holm, Marc Jegers, Pierre-Guillaume Méon, Paolo Pinotti and an anonymous referee for insightful comments and suggestions. Financial support from FWO Vlaanderen (grant number G.0022.12) is also gratefully acknowledged. Data and code are available upon request.

\section{Disclosure statement}

No potential conflict of interest was reported by the authors.

\section{Notes}

1. A similar network mechanism has also been brought forward to explain the formation and success of political dynasties (Dal Bó, Dal Bó, \& Snyder, 2009; Daniele, 2015). Likewise, Mastrobuoni (2015) convincingly documents the economic value of network connections within the Italian-American mafia in the 1960s.

2. A large literature links interpersonal trust to economic growth and development. For a recent discussion of this extensive literature and an integrative contribution to it, see Bjørnskov and Méon (2013).

3. Specifically, the first question asks 'How important is family in your life?' and takes values from 1 (not important at all) to 4 (very important). The second question measures respondents' agreement with one of two statements: (1) 'One does not have the duty to respect and love parents who have not earned it'; (2) 'Regardless of what the qualities and faults of one's parents are, one must always love and respect them'. The third and final question again measures respondents' agreement with one of two statements: (1) 'Parents have a life of their own and should not be asked to sacrifice their own wellbeing for the sake of their children'; (2) 'It is the parents' duty to do their best for their children even at the expense of their own wellbeing'.

4. The eigenvalue of the first factor deriving from this PCA is equal to 1.24 , and it explains 41.9 per cent of the variance in responses. The factor loadings for each element included in the PCA exceeds 0.53 .

5. For more information on this classification, see http://data.worldbank.org/about/country-classifications/a-short-history. Note also that while we report only the split-sample results in detail below, models with interaction effects provide similar results. For ease of interpretation, Figure A1 in the Online Appendix visualises the marginal effect of family ties across the different country groups in these interaction models, which are estimated using multilevel models - where individuals (level 1) are nested within countries (level 2) and the family ties variable is interacted with the World Bank classification index (details available upon request).

6. Our results do not change if we use logit or probit models instead of OLS (available upon request).

7. The slight difference in our results is due to our specification of respondents' marital status. Alesina and Giuliano set the indicator variable for married individuals to 1 only for individuals declaring to be 'living together as married (but not married)', while we also set it to 1 for married individuals. Although this does not affect any of the results reported below, and we can exactly replicate Alesina and Giuliano's original results using their specification, we consider our operationalisation more appropriate.

8. Magruder (2010) studies formal labour markets, and it is not intuitively clear whether similar gender differences in the labour market advantage of family networks would likewise arise in informal labour markets. Unfortunately, the EVS/WVS does not differentiate between formal and informal labour markets, which implies that we cannot empirically verify such potential formal-informal sector differences. This clearly remains an important avenue for future research.

9. Also in this case, we refer to Alesina and Giuliano (2011) for detailed tests of the direction of causality.

10. Interestingly, recent work has started taking limited steps towards such a line of research. Brumm and Brumm (2014), for instance, show that intra-family altruism might hinder economic reforms even in periods of economic crisis, while Alesina et al. (2015) model a game where societies characterised by strong family ties vote for stricter labour market regulation. 


\section{References}

Alesina, A., Algan, Y., Cahuc, P., \& Giuliano, P. (2015). Family values and the regulation of labor. Journal of the European Economic Association, 13, 599-630. doi:10.1111/jeea.12121

Alesina, A., \& Giuliano, P. (2010). The power of the family. Journal of Economic Growth, 15, 93-125. doi:10.1007/s10887-0109052-Z

Alesina, A., \& Giuliano, P. (2011). Family ties and political participation. Journal of the European Economic Association, 9 , 817-839. doi:10.1111/j.1542-4774.2011.01024.x

Alesina, A., \& Giuliano, P. (2013). Family ties. In P. Aghion \& S. N. Durlauf (Eds.), Handbook of economic growth (Vol. 2A). Amsterdam: Elsevier.

Banfield, E. C. (1967). The moral basis of a backward society. New York, NY: Free Press.

Bertrand, M., \& Schoar, A. (2006). The role of family in family firms. Journal of Economic Perspectives, $20,73-96$. doi:10.1257/jep.20.2.73

Bjørnskov, C., \& Méon, P.-G. (2013). Is trust the missing root of institutions, education, and development? Public Choice, 157, 641-669. doi:10.1007/s11127-013-0069-7

Brumm, E., \& Brumm, J. (2014). Reform support in times of crisis: The role of family ties. Unpublished manuscript.

Cervellati, M., Jung, F., Sunde, U., \& Vischer, T. (2014). Income and democracy: Comment. American Economic Review, 104, 707-719. doi:10.1257/aer.104.2.707

Dal Bó, E., Dal Bó, P., \& Snyder, J. (2009). Political dynasties. Review of Economic Studies, 76, 115-142. doi:10.1111/j.1467937X.2008.00519.X

Daniele, G. (2015). Born in the purple? Dynastic politicians and electoral success. Unpublished manuscript.

Dreher, A., Méon, P.-G., \& Schneider, F. (2014). The devil is in the shadow. Do institutions affect income and productivity or only official income and official productivity? Public Choice, 158, 121-141. doi:10.1007/s11127-012-9954-8

Durante, R., Labartino, G., \& Perotti, R. (2015). Academic dynasties: Decentralization and familism in the Italian academia. Unpublished manuscript.

Duranton, G., Rodríguez-Pose, A., \& Sandall, R. (2009). Family types and the persistence of regional disparities in Europe. Economic Geography, 85, 23-47. doi:10.1111/j.1944-8287.2008.01002.x

Ermisch, J., \& Gambetta, D. (2010). Do strong family ties inhibit trust? Journal of Economic Behavior \& Organization, 75 , 365-376. doi:10.1016/j.jebo.2010.05.007

Galasso, V., \& Profeta, P. (2012). When the state mirrors the family: The design of pension systems. Unpublished manuscript.

Gërxhani, K. (2004). The informal sector in developed and less developed countries: A literature survey. Public Choice, 120, 267-300. doi:10.1023/B:PUCH.0000044287.88147.5e

Helmke, G., \& Levitsky, S. (2004). Informal institutions and comparative politics: A research agenda. Perspectives on Politics, 2, 725-740. doi:10.1017/S1537592704040472

Luke, N., Munshi, K., \& Rosenzweig, M. (2004). Marriage, networks, and jobs in third world cities. Journal of the European Economic Association, 2, 437-446. doi:10.1162/154247604323068122

Magruder, J. R. (2010). Intergenerational networks, unemployment, and persistent inequality in South Africa. American Economic Journal: Applied Economics, (2), 62-85. doi:10.1257/app.2.1.62

Mastrobuoni, G. (2015). The value of connections: Evidence from the Italian-American Mafia. The Economic Journal, 125, F256-F288. doi:10.1111/ecoj.12234

Montgomery, J. D. (1991). Social networks and labor-market outcomes: Toward an economic analysis. American Economic Review, 81, 1408-1418. Retrieved from http://www.jstor.org/stable/2006929

Munshi, K. (2003). Networks in the modern economy: Mexican migrants in the U. S. labor market. The Quarterly Journal of Economics, 118, 549-599. doi:10.1162/003355303321675455

Rosenzweig, M. R., \& Stark, O. (1989). Consumption smoothing, migration, and marriage: Evidence from rural India. Journal of Political Economy, 97, 905-926. doi:10.1086/jpe.1989.97.issue-4

Wahba, J., \& Zenou, Y. (2005). Density, social networks and job search methods: Theory and application to Egypt. Journal of Development Economics, 78, 443-473. doi:10.1016/j.jdeveco.2004.11.006

Wang, S. (2013). Marriage networks, nepotism, and labor market outcomes in China. American Economic Journal: Applied Economics, 5, 91-112. doi:10.1257/app.5.3.91 